\title{
Легенда о святой Урсуле в старой польской и восточнославянской письменности (XVI-XVII вв.)
}

\author{
АНДРАШ ЗОЛТАН \\ Zoltán András, ELTE Keleti Szláv és Balti Tanszék, Budapest, Múzeum krt. 4/D, H-1088 \\ E-mail: zoltand@ludens.elte.hu
}

\begin{abstract}
The variant of the Saint-Ursula-legend, which is preserved in the Polish chronicle written by Maciej Stryjkowski (Königsberg 1582) and put in the Hunnish period, is an unaltered borrowing from Cyprian Bazylik's Polish translation (Cracow 1574) of Miklós Oláh's work (Nicolaus Olahus) Athila (Basel 1568). Around 1580 an anonymous Belorussian translation was made from this Polish version in Vilna (Vilnius). As Cyprian Bazylik, the first translator did not indicate the name of the author (that is of Miklós Oláh) in his Polish translation (1574), the later translators, both Stryjkowski and the unknown Belorussian one, carried on this legend without mentioning its author. Later, in the 17th century Stryjkowski's chronicle was translated twice into Russian Church Slavonic and in this way the Ursulalegend, as part of these translations, got into the Russian literature in the version formulated by the Hungarian humanist Miklós Oláh. At the end of our study we publish the text of the Ursula-legend in the following variants: 1) the original Latin work of Miklós Oláh (1568), 2) Cyprian Bazylik's Polish translation (1574), 3) the anonymous Old Belorussian manuscript translation (around 1580), 4) the legend according to the Polish chronicle of Maciej Stryjkowski (1582), 5) the anonymous Russian Church Slavic translations of 1673-1679 and 6) 1688.

Keywords: the Saint-Ursula-legend, Miklós Oláh (Nicolaus Olahus), Hungarian-Polish literary contacts, Cyprian Bazylik, old Polish literature, Maciej Stryjkowski, old Belorussian literature, Polish-East-Slavic contacts, old Russian literature
\end{abstract}

Многочисленные западноевропейские святые обязаны своим статусом святого гуннам или непосредственно их королю Аттиле. Во Франции это - святая Геновева (Geneviève, патронесса Парижа), св. Аниан (Aignan, епископ Орлеана), св. Луп (Loup, епископ Tруа), св. Никазий (Nicaise, епископ Реимса), св. Мартин и св. Ремигий (Remi, cм. Löfstedt 1993, 69), в Италии - св. Геминиан (епископ Модены) и Иоанн (епископ Равенны). Не все они пострадали во время гуннского вторжения в Галлию (451 г.) или в Италию (452 г.), некоторые из них жили столетиями раньше или позже, но сложившаяся позднее традиция связывает их подвиг или мученическую смерть именно с гуннами (Eckhardt 1940, 158-170).

К ним примыкает св. Урсула из Кельна, поскольку мученичество этой святой вместе с 11 тысячами благородных девиц традиция связывает с походом Аттилы в Галлию. В основу традиции лег камень с надписью, согласно которой некий Клематий (Clematius) восстановил разрушенную церковь на месте, где «святые девы пролили свою кровь во имя Христово». В IX в. девицы во главе с Урсулой получают имена, их число постепенно достигает 11. Невероятное число 11 тысяч девиц 
получилось из 11 мучениц вследствие ошибочного прочтения сокращенного написания XI M Virg как XI Milia Virginum '11 тысяч девиц' вм. XI Martyres Virgines '11 мучениц-девиц'. В Х в. возникли первые «Страсти Урсулы» (Passio Ursulae), в которых Урсула является дочерью британского короля, которая вместе с этими 11 тысячами девиц совершает паломничество в Рим. Девицы едут кораблями по Рейну до Базеля, оттуда отправляются пешком в Рим, где молятся на могилах святых апостолов и обходят все святые места. После этого они отправляются тем же путем назад. На обратном пути они приближаются к Кельну, который к этому времени занят гуннами. Девицы, не предвидя опасности, сходят с кораблей, и гунны убивают их всех стрелами из лука (cm. CathEn s. v. St. Ursula and the Eleven Thousand Virgins; KatLex III, 456; ÖHL s. v. Ursula).

Гунны попали в эту историю не по своей вине, а по вине венгров, так как автор первых «Страстей Урсулы» написал свое сочинения для монахинь из Герресхейма, монастырь которых в 922 г. был разрушен венграми. Таким образом, в легенде о святой Урсуле отражается западноевропейское отождествление венгров с гуннами (Eckhardt 1940, 163-165).

Отождествление это в своем намерении никак не было лестным для венгров. На Западе, особенно во Франции, Аттила и гунны воспринимаются как олицетворение сатаны. Но гуннов отождествляют с венграми, как известно, и сами венгры. Средневековые венгерские хронисты на протяжении нескольких столетий разрабатывали и обосновывали тезис о гунно-венгерской преемственности, сначала только правящей династии, а потом и всего народа. В венгерском этногенетическом мифе история гуннов выступает как предыстория собственно венгерской истории, как первый «исход» венгров из Скифии, предвосхитивший их второй «исход», в результате которого в конце IX в. венгры окончательно поселились в Карпатском бассейне. Если в западном изображении Аттилы и гуннов преобладают самые отрицательные их черты, они предстают как лютые враги христианства, то у венгерских хронистов тот же Аттила со своими гуннами выступают с одной стороны как славные предки, с другой - как язычники. Эта двойственность в оценке поступков гуннов наблюдается у венгерских авторов и во время Ренессанса. Венгерские авторы как венгры могут восхищаться победами гуннов и сочувствовать им в случае поражений, но как христиане они вынуждены осуждать «своих» за приписиваемые им западноевропейскими христианскими источниками зверства вроде убийства христианских мучеников.

Легенда о святой Урсуле попадает в венгерские хроники, а затем и в такие сочинения, как латиноязычное произведение Athila венгерского гуманиста Миклоша Олаха (Nicolaus Olahus, 1493-1568). Это сочинение (Olahus 1938, 35-72) стало самым популярным в Восточной Европе произведением венгерской литературы XVI в. Оно было написано 
в 1537 г. в Нидерландах во время пребывания автора в Брюсселе в качестве секретаря королевы-вдовы Марии Габсбург и впервые было опубликовано в 1568 г. в Базеле в качестве вставки в большой труд Антонио Бонфини по венгерской истории Rerum Ungaricarum Decades (cм. Olahus 1938, VI; Bonfini 1936, XXXVII; 244; Graciotti 1973, 286-287). Сочинение М. Олаха - без указания автора - уже в 1574 г. было издано в Кракове на польском языке в переводе Циприана Базылика (Bazylik 1574). На основе польского текста ок. 1580 г. был подготовлен анонимный старобелорусский рукописный перевод (Атыля 1580), повидимому, в Вильно (см. Brückner 1886, 376-384; Веселовскій 1888, 125131, 339-340) Graciotti 1973, 312-316; о существующих изданиях старобелорусского текста см. Zoltan 2000).

На основе сравнения этих трех версий можно установить, что полное отождествление гуннов с венграми - это дело польского переводчика. Поскольку единственный сохранившийся экземпляр польского издания является дефектным, установить, что Аттилу из короля гуннов в «угорского короля» превратил как раз польский переводчик можно на основе латинского и старобелорусского текстов. В начале повествования М. Олах говорит определенно о гуннах («Hunni»). Ц. Базылик судя по старобелорусскому тексту — в своем польском переводе уже с самого начала отождествлял гуннов с венграми; при первых случаях употребления этнонима гунны он добавляет объяснения типа «гунны, которых теперь обычно зовут венграми», «в Паннонии, т. е. в той стране, которую мы теперь называем Венгрией», а дальше в ходе повествования он говорит только о венграх, приписывая тем самым все подвиги (а также все преступления) гуннов венграм (ср. Zoltán 1996, 430; Золтан 1999, 78, Zoltán 2001). Таким образом, вскоре после выхода в свет латинского оригинала сочинения Олаха, легенда о св. Урсуле в версии венгерского гуманиста была уже доступна на польском и старобелорусском языках, с тем, однако, отклонением от орининала, что в этих версиях говорилось не о гуннах, а о венграх (тексты см. ниже). Однако ни в польском издании, ни, тем более в старобелорусской рукописи не было указано имя автора, поэтому в Польше и Литве это сочинение распространилось анонимно. (Авторство Олаха было установлено лишь в конце XIX в. А. Брюкнером, см. Brückner 1886, 379-381).

Текст М. Олаха в переводе Ц. Базылика был использован польским хронистом М. Стрыйковским в его «Хронике польской, литовской, жемайтской и всей Руси» (Кёнигсберг, 1582) ${ }^{1}$. Останавливаясь на вопросе о происхождении литовцев от римлян, он приводит разные

${ }^{1}$ В дальнейшем ссылки даются в основном на первое издание «Хроники» Стрыйковского (Stryjkowski 1582; мы пользовались экземпляром Библиотеки Рачинских в Познани). В литературе предмета чаще всего цитируется т. н. «новое» издание, осуществленное М. Малиновским в 1846 г. (Stryjkowski 1846). Интересующие нас фрагменты имеются также в рукописном варианте сочинения из 1577 г., опубликованном Ю. Радзишевской (Stryjkowski 1978). 
варианты этого этногенетического мифа, в том числе и тот, в котором бегство Палемона с пятьюстами знатными римскими семействами из Рима в устье Немана объяснялось кровавыми походами Аттилы на Западную Европу («dla frogiego á okrutnego Woyfká Atile Krolá Węgierfkiego, ktory práwie wßyftki zachodnie kráiny y inße mocne páńftwá száblą á ogniem w ten czás burzył, iák o tym ßerzey Kroniki ftáre Węgierfkie y Callimachus Florentinus, tákże Bonfinus y inßy fwiádczą» - Stryjkowski 1582, 49). Эта версия вдохновила М. Стрыйковского пересказать стихами всю гуннскую («венгерскую») историю. В стихотворный текст в одном месте он ввел в скобках обстоятельную вставку в прозе, чтобы при случае рассказать легенду о святой Урсуле. Если сравнить текст этой вставки с соответствующим местом перевода Ц. Базылика и оригинала М. Олаха, то нетрудно убедиться в том, что М. Стрыйковский практически списал текст Ц. Базылика (ср. Золтан 1999, 85-88). Таким образом, благодаря этому небольшому плагиату фрагмент текста М. Олаха в переводе Ц. Базылика, хотя и анонимно, но вошел в состав очень популярного в свое время сочинения М. Стрыйковского (cp. Zoltán 2000a). Ради справедливости следует отметить, что в одном другом месте, где говорится о гепидах и остроготах как о союзниках «венгров», М. Стрыйковский на полях все-таки ссылается на это сочинение ( «O tym czytay / Hiftorię od / Bafilica Cy-/priana prze-/łożoną» — Stryjkowski 1582, 54; cp. Krzyżanowski 1926, 153; нет этой ссылки в рукописном варианте «Хроники» 1577 г., см. Stryjkowski 1978, 68).

В XVII в. «Хроника» М. Стрыйковского была переведена на старобелорусский язык и дважды на русский (русско-церковнославянский) язык (см. Соболевскій 1903: 79-80; Рогов 1966: 259-306, cp. Bardach 1967, Graciotti 1973: 316). Вместе с переводом всей «Хроники» была переведена и легенда о святой Урсуле в версии М. Олаха, заимствованная М. Стрыйковским из польского перевода Ц. Базылика 1574 г. Таким образом этот небольшой фрагмент сочинения венгерского гуманиста - хотя и анонимно - вошел не только в польскую и белорусскую, но и в русскую литературу.

Ниже нами приводятся тексты легенды о святой Урсуле в версии М. Олаха. Латинский оригинал (1) цитируется по критическому изданию К. Эперьеши и Л. Юхаса (Olahus 1938), польский перевод Ц. Базылика (2) - по уникальному экземпляру Библиотеки Польской Академии наук в Курнике (Biblioteka Kórnicka PAN, шифр: Cim. O. 226; см. Bazylik 1574)2, старобелорусский перевод (3) - по Познанскому сборнику (Атыля 1580). Текст соответствующего отрывка из «Хроники» M. Стрыйковского (4) дается по первому печатному изданию (Stryj-

2 Об этом издании см. Estreicher XIV, 21-22, Wierzbowski III, 130-131 (nr 2589), Piekarski I, 24, 31, tabl. V (nr 162), Polonica Typographica XI, 57-58, tabl. 523 (nr 96). В указанных работах авторство переведенного Ц. Базыликом сочинения приписывается Каллимаху (Callimachus Experiens [Filippo Buonaccorsi, 1437-1496]) несмотря на то, что ошибочность такой аттрибуции была доказана уже А. Брюкнером (cp. Zoltán 2001b).

Studia Slavica Hung. 48, 2003 
kowski 1582). Тексты обоих русских рукописных переводов «Хроники» М. Стрыйковского цитируются по спискам конца XVII в., хранящимся в Государственном историческом музее в Москве: перевод 1673-1679 гг. (5) - по рукописи Музейное собрание, № 1391, а перевод 1688 г. (6) по рукописи Уваровское собрание, № 4. Тексты 5 и 6 публикуются впервые.

\section{Тексты}

\section{1.}

Nicolaus Olahus, Athila (Caput XI.)

Dum haec ad Remensem urbem ita, ut memoravimus aguntur, interea Athila quendam exercitus sui ducem Gywlam vel (ut quidam volunt) Iulium nomine cum parte copiarum misit, qui Coloniam Agrippinam, civitatem tunc quoque (ut nunc) insignem et am plam obsideret. Is, ut iussum erat, urbem forti cinxit obsidione. Ea tempestate Aethereus Anglorum regis filius pulchritudine, virtute ac moribus divae Ursulae Britanniae regis filiae unigenitae ardentissime commotus eius per legatos apud patrem ambire coepit connubium. Quem, quum sollicitus esset, quid responsi daret legatis, Ursula anxium moestumque admonet, ut deposita animi sollicitudine Aethereo eam despondeat; oraculo enim se accepisse, ne id detrectatura esset ea lege matrimonium, ut triennium illi consummando concederetur, quo peregrinationem a se votam interea exequi posset, hanc autem eam esse, ut urbem Romanam comitata decem millibus virginum inviseret; proinde ipse et Aethereus procus curarent pari opera decem spectatae pudicitiae virgines conquirere, harum singulis mille et sibi quoque totidem subdere, quarum spectata esset omnium probitas ac pudicitia. Legati accepto a patre Ursulae hoc responso laeti redeunt. Aethereus et Britanniae rex Ursulae pater concsripto, ut designatum erat, virginum agmine eas Ursulae sodalitio adiungunt.

Quae accepta hac nobili societate atque comparatis undecim magnis navibus aliisque rebus in peregrinationis usum necessariis ex Britannia ad ostia Rheni, ubi nunc Hollandiae pars est, applicuit. Unde adverso flumine Coloniam cum magno civium applausu ac laeticia, ex Colonia Basileam pervenit. Ibi relictis navibus cum aliis impedimentis pedestri itinere Romam proficiscitur. Quae tandem sanctorum reliquiis et sacris omnibus locis, ut eius erat votum, Romae perlustratis Basileam revertitur Cyriaco papa, cuius alii (praeter scriptorem historiae eccelsiasticae, quod sciam) autores nullam faciunt mentionem, eam summo ubique honore prosequente. Conscensa igitur ad Basileam navi secundo Rheni flumine Coloniam devehitur. Quae egressa in continentem nihilque hostile, sed omnia (ut antea) tuta esse arbitrata, ubi urbi appropinquare coepit, mox ab Hunnis undique invaditur atque cum omni societatis suae turma crudelissime trucidatur. Ita sanctissima virgo suo, Aetherei sponsi (qui accepto Ursulae reditu cum matre et sorore Florentina nonnullisque aliis episcopis Coloniam usque ei obviam venerat) atque Cyriaci pontificis ac caeterarum virginum sanguine pudicitiam suam Christo domino virginitatis vero sponso consecravit. Harum reliquiis illustris est Colonia. Inter seriptores non satis convenit de huius necis tempore. Verum, quoniam chronica nostra hoc tempus virginum trucidatarum tradunt, creditu non absurdum est per id tempus, quo Athila erat in Gallia, Ursulam cum suis virginibus fuisse ab Hunnis necatam.

(Olahus 1938, 57-58) 
2.

Hiftoria fpraw Atyle Krolá Węgierfkiego

Z Łacińfkiego ięzyká ná / Polfki przełożoná / przez Cyprianá / Bazyliká

(F3v:) $[\ldots]$

Kápitułá xi.

To gdy fie w Remeńfkim miefcie / działo, Atylá niektorego Hetmá/ná fwego Giułe, álbo (iáko go / niektorzy zową) Juliufá, dawf3y mu / niemáłą cżęść woyská fwego, pofłał / do Kolná ktore zową Agryppiná, áby / go dobywał, ktore miáfto iáko theráz / ták y ná on cżás było zacne y wielkie.

W ten cżás Etereus fyn Krolá Angiel/fkiego, młodzieniec głádki, cnotliwy y / dobrych obycżáiow, pocżął sie stháráć / w małżeńftwo o Vrf̧̋lę, Brytáńfkie-/go Krolá dziewkę iedynacżkę, pofła-/wfзy z wielką chęcią posły do ojcá iey. / Ktorego, gdy niewiedział coby zá od-/powiedź dáć miał, Urfzulá smętnego / y throfkliwego nápomniáłá, áby da/wf3y frásunkom pokoy, záręcżył ią zá / Etereufá, powiedáiąc że ma tho obiá-/wienie od Bogá, áby fie nie zbraniáłá / małżeńftwá te ${ }^{\circ}$, w ten fpofob, żeby iey / iefzcże dano wolne trzy látá, przez kto-/reby odpráwiłá drogę fwoię ná ktorą // (F4:) fie byłá obieczáłá, tho ieft, áby f̧̉łá do / Rzymu, máiąc przy fobie dziefięć tyfię-/cy pánien. A przetoż, tego fie domagá-/łá, áby y on, y Etereus pánic iey, stárá-/li fie fpolnie, iákoby iey náleźli dziefięć / pánien, ofobney cżyftośći y státecżno-/śći, á káżda z nich, áby miáłá przy fo-/bie tyfiąc pánien, y oná fámá áby theż / tákże przy fobie tyfiąc miáłá, iedno że-/by wf̧ytki były ofobliwey cnothy y cży-/Itośći. Posłowie, wziąwfз̌y od oyczá / Urfzule tę odpowiedź, z rádofćią odie-/cháli.

Etereus y Brytáńfki Krol, ociec Ur-/\{̧ule, zebrawf̧y wedle zmowy, ták wie-/le pánien, dáli je Urß̧uli w thowárzy-/ftwo, ktora przyiąwfзy to fláchetne to-/wárzystwo, á fpráwiwf̧y iedennafcie / wielkich okręthow, y drugie rzeczy ná / ták dáleką drogę potrzebne, puśćiłá fie / morzem z Brytanniey áż do tego miey-/ /cá gdzie Ren w morze wpada, gdzye / teraz ieft cżeść Hollándiey, skąd zálię rze/ką przećiw wodzie przyiecháłá do Kol-/ná $\mathrm{z}$ wielką rádofcią mief̧̌czánow, á s / Kolná do Bázyleiey. Tám zostáwi-/wf̧̌y okręty,

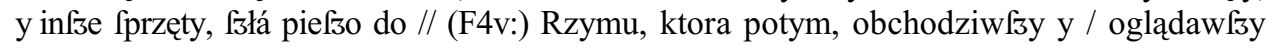
mieyscá y fwiątośći wfзy-/tki w Rzymie, iáko byłá obiecáłá, wro-/ćiła fie do Bazyleiey, á Papież Cyryak / prowádził ią z wielką vcżćiwofcią áż / do mieyscá. Wfiadf̧y tedy v Bázyleiey / w okręth, Renem rzeką ná doł iecháłá / do Kolná, kthora wyliadfry ná brzeg, / nic fie nieprzyiacielá nie fpodziewaiąc, / ale mnimáiąc áby ták wfзsytko befpie/cżno było iáko pirwey, gdy fie do miá-/ftá przybliżác poczęłá, wnet ią Węgro-/wie ze wf̧ech ftron obfkocżyli, á z one-/mi wfisitkiemi pánnámi okrutnie pozá-/biyali. Thákci oná fláchetna pánná, z / Etereufem pánicem fwoim, (ktory do/wiedziawf̧y fie że Vrf̧ulá ná zad ie-/dzie, z mátką y s fiostrą Florentyna, y z / niektoremi inf̧emi Biskupy, áż do Kol/ná przećiwko niey był wyiechał) y z o-/nym Cyriakiem Papieżem, y ze wf̧̌ytki/mi onemi pánnámi, s tego fwiátá ze-/f̧̉łá, á cżyftość fwą Kryftufowi, praw-/dziwemu dziewicthwá oblubieńcowi / ofiárowáłá. Tych pánien ciáłá leżą w / Kolnie. Hiftorikowie nie zgadzáią fie / o cżáfie tego pobicia. Ale iż Kroniká // (F5:) Węgierfka ftára, ten cżás pobicia tych / pánien być powieda, podobna rzecż / ieft $\mathrm{k}$ wierze, iż $\mathrm{w}$ ten cżás gdy Atylá we / Fránciey był, Vrf̧ulá s pánnámi fwo-/imi, byłá od Węgrow zábitá.

(Bazylik 1574, F3v-F5) 
3.

Исторығ $\omega$ Атыли короли Угоръскомъ

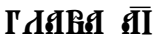

(206:) [...] То кгды са в ремэн сво?го // (207:) Кгюлу, албо ғккъ его нькоторыє зовуть юлюса, давшы ему немалую ча ${ }^{\text {сть }}$ во $^{s}$ ска своего послалъ до колна котороє зовуть Агрыпъпина, абы єго добывал. Котороє мъ ст о /нкъ тепер, такъ и на $\omega^{\text {н } ч а с ъ ~ б ы л о ~ з а ~}$

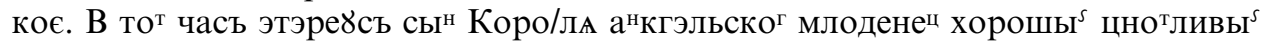
и добры ${ }^{\mathrm{x}} \omega б ы ч а \epsilon^{\mathrm{B}}$ почалъ са старать / в малъжен Корола дъвку

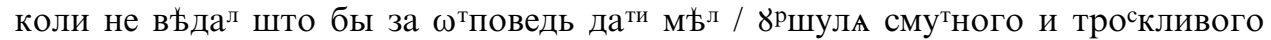
напо ${ }^{\mathrm{H}}$ ела, абы давшы өрасунъко ${ }^{\mathrm{M}}$ поко ${ }^{s}$ заручы ${ }^{\text {I }}$ ее за этэредса поведаючы ${ }^{ж}$ маєть тоє $\omega$ бъАвеньє $\omega^{\mathrm{T}}$ бога абы са не збо/ронала малженства того в то ${ }^{\mathrm{T}}$ способ, иж $^{\text {бы } \epsilon^{s} \text { єще дано волныє тры льта, / чере }{ }^{3} \text { которыє бы } \omega^{\mathrm{T}} п р а в и л а ~ д о р о г у ~ с в о ю ~}$ на которую са была шбецала, то е

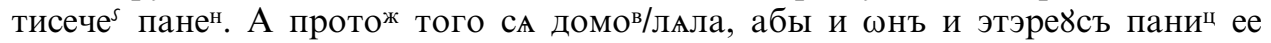
старалиса сполне ғакъ бы $\epsilon^{s}$ нашли де/сеть панен $\omega$ соб$^{6}$ ное чыстости и статэчности, а кождаА 3 ни ${ }^{\mathrm{x}}$ абы мъла пры / собъ тисечу панен, и также пры собе тисечу мظла,

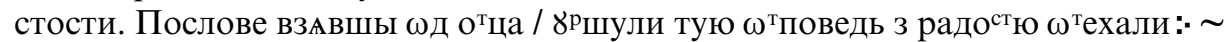
Этэреґсь, и брытански и король

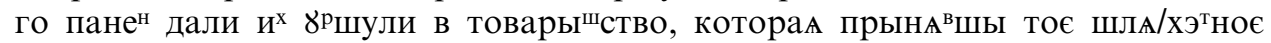

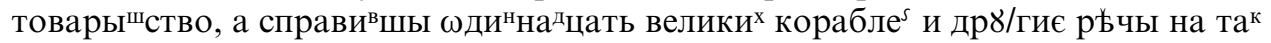

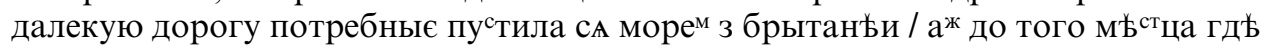

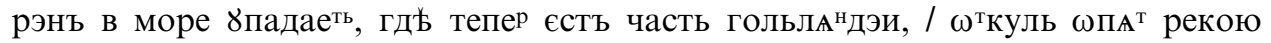
проти ${ }^{\mathrm{B}}$ воды прыехала до кольна з великою радо ${ }^{\text {ст }}$ / мещановъ, А с кольна до базыльи. Тамъ зоставившы корабли и иннэ / спраты шла пьша до рыму, КотораА потомъ $\omega^{6}$ ходи ${ }^{\text {вшы и }}$

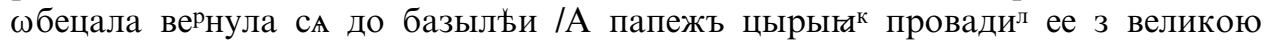
поче ${ }^{\mathrm{cT}}$ ностью, ажъ до мь ${ }^{\text {ст } ц а, ~ / ~ В с ъ в ш ы ~ т э д ы ~} 8$ базылеи 8 корабль рэно ${ }^{\text {мъ }}$ рекою на до ${ }^{\pi}$ ехала до кольна / котораА выседшы на берегъ ничого сА непрынтелА не

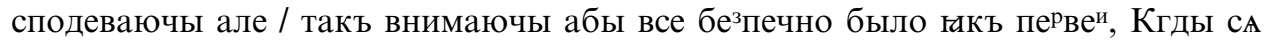
до мъста пры/ближа ${ }^{\text {ти почала, тогды ее } г г р о в е ~} 30$ вси $^{\mathrm{x}}$ сторо ${ }^{\text {н }} \omega^{6}$ скочыли, а

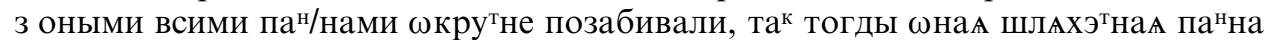

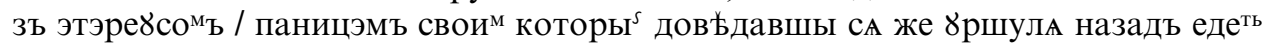

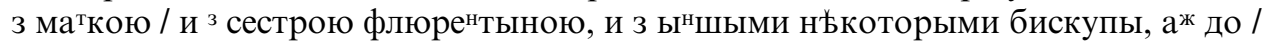
кольна противъ ее бы ${ }^{\text {в }}$ выеха ${ }^{\pi}$ и $з$ оны ${ }^{\mathrm{M}}$ цырынко ${ }^{\mathrm{M}}$ папежо ${ }^{\mathrm{M}}$, и зо всими / пан ${ }^{\mathrm{H}}$ нами С того свьта зошла, А чыстость свою хрыстусу // (208:) пра

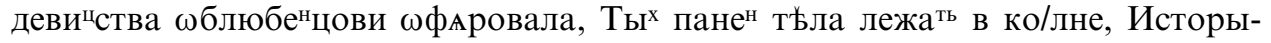

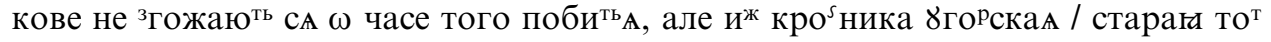

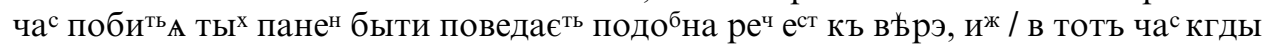

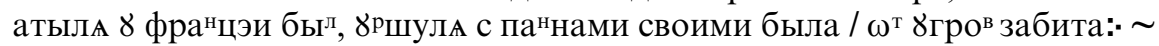

(Атыля 1580, 206-208) ${ }^{3}$

${ }^{3}$ Ср. издания: Веселовскій 1888, Приложения, 212-214, Микитась 1988, 425-426. 
4.

Maciej Stryjkowski, Kronika Polfka Litewfka, Zmodźka, y wßyftkiey Rufi [...]

(51:) $[\ldots]$

Giulę Hetmaná fwego pod Kolno wypráwił,

Ktory obozy fwoie ná czworę rozftáwił,

Y ták dobywał miáftá dniem nocą fturmuiąc.

Wśi, Wołoscy w około fzeroko plundruiąc.

(Wten czas Etereus, Syn Krolá Angellkiego począł fie ftáráć, w Małżeń-/ftwo o Vrfulę Brytańlkiego krolá dziewkę iedynaczkę, polław f̧̌y z wielką chę-/cią polły do Oicá iey, ktorego, gdy niewiedział coby zá odpowiedz dáć miał, Vr-/fula fmętnego i trofkliwego nápomináłá, áby dawf̧y frasunkom pokoy záręczeł / ią zá Etereufa, powiedáiąc, że ma to obiáwienie od Bogá, áby fię niezbraniałá // (52:) Małżeńftwá tego, wten fpofob żeby iey dano iefzcze wolne trzy látá, przez ktore-/by odpráwiłá drogę fwoię, ná ktorą fie byłá obiecáłá: To ieft áby f̧łłá do Rzymu, / máiąc przy fobie dziefięć tyfięcy pánien. A przetof3 tego fie domagáłá, áby y Oćiec / y Etereus pánic iey ftáráli fie społnie, iákoby iey náleźli 10 pánien ofobney czyfto-/śći y ftátecznośći, á káżda znich áby miáłá przy fobie tyfiąc pánienek, y oná famá / áby też tákże przy fobie tyfiąc miáłá, iedno żeby wf̧ytki beły ofobliwey cnoty y / czyftośći. Pofłowie wziąwfzy od Oycą Vrfulinego tę odpowiedź z rądofcią od-/iecháli.

Ták tedy Etereus, y Britáńfki Krol, Ociec Vrfule, zebrawf̧y wedle zmowy / ták wiele pánien, dáli ie Vrfuli w towárzystwo, która przyiąwfзy to fláchetne to-/wárzyftwo, á fpráwiwf3y 11. wielkich okrętow, y drugie rzeczy ná ták dáleką dro-/gę potrzebne, puściłá fie morzem z Britanniey áż do tego mieyfcá gdzie Ren w / morze wpada, gdzie teraz ieft część Holandiey, fkąd záfię przećiw wodzie rzeką / przyiecháłá do Kolna Agripiny, z wielką rádością mief̧̌czánow, A s Kolná do / Bazileiey Tám zoftáwiwfß̋y okręty y infze fprzęty, f̧łłá piefžo do Rzyma, ktora / potym obchodziwf̧y mieyfcá wf̧sytki w Rzymie, iáko byłá obiecáłá, wroćiłą fie / do Bazyliey, á Papież Cyriák prowádził ią z wielką poczćiwośćią áż do mieyfcá.

Wfiadf3y tedy v Baziliey w Okręty Renem rzeką ná doł iácháłá do Kolná, Támże wyliádłá ná brzeg nic fie nieprzyiacielá niefpodziewáiąc, ále mnimáiąc / áby ták wfłsytko befpieczno było iáko pirwey, á gdy fię do miáftá przybliżáć poczę-/łá, wnet ią Węgrowie ze wf̧ech ftron obfkoczyli, á z onymi wfзsytkimi pánnámi / okrutnie pozábiiáli. A ták oná fláchetna Pánná z Etereuf̧em Pánicem fwoim, / ktory dowiedziawf̧y fie, że Vrfula ná zad iedzie, z mátką y z fioftrą Florentiną y / z niktorymi infzymi Biskupy áż do Kolna przećiwko niey był wyiechał, y z onym / Cyriakiem Papieżem, i ze wfzytkimi pánnámi z tego Swiátá zefzłá, á czyftość / fwą Chriftufowi prawdziwemu dziewictwá oblubieńcowi ofiárowáłá.

Tych pá-/nien ciáłá leżą w Kolnie. A potym kośći ich w wielki sklep fą złożone. Tą Histo-/riyką dla tegom rzecz przerwał, if̧ też w Litewskich ftárych látopif̧czach około / Burzenia Atile y pobicia tych iedenaśćie tyfiąca dziewic, á [sic!] przyczynie przyśćia / Włochow s Palemonem do Litwy, iakoby przes fen ledáiáko wfpomináią. / Przetom to inter parente (im położył.)

Do Węgier fie zwroćiwfзy Budę zámordował

Brátá, if sikambrią od fiebie miánował

Buda: ktory iednak dziś też Budzyniem zową,

Ktoremu (Ach Węgrowie), 'I'urek teras głową.

$[\ldots]$

(Stryjkowski 1582, 51-52)

Studia Slavica Hung. 48, 2003 
5.

Русский перевод 1673-1679 гг.

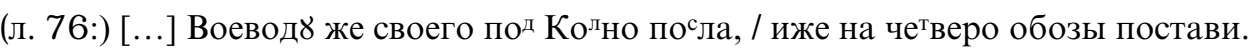
днемь и ночью добивағ грады, волости же / '̈̈ веси в' конецъ разорАғ. [в' то времғ Етере // (л. 76 об.:) сынъ королға аглинскаго нача тщатисА / в' супруж_ ство Урсхли дщери королю британъ/скаго единицы, пославъ пословъ своихъ /

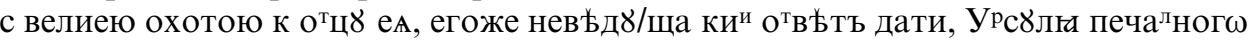
/ увещеваше да о ставивъ печа ${ }^{\text {т }}$ обрұчилъ / ю, Етерию повьдан нко има ${ }^{\mathrm{T}}$ то во

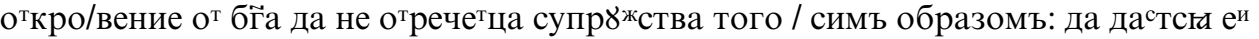
свобода на три / льта, в нғже путь сво и скончаетъ. егоже / обеща се есть да

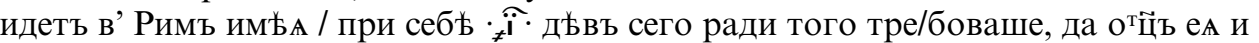

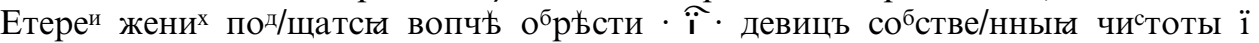

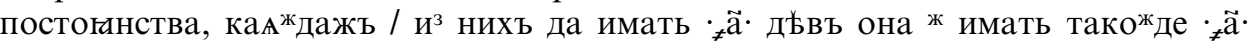

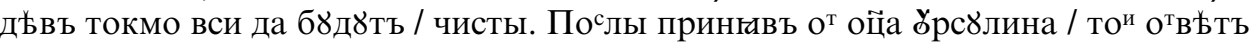
с радос тию о идоша.

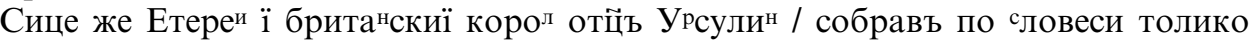

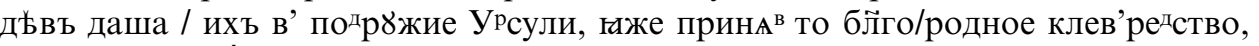

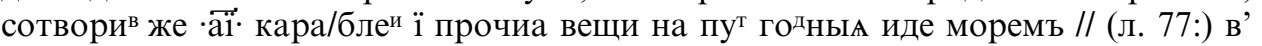
Британию даже до мъста їдъже Ренъ река / в' море в'падаеть, їдъже нйъ часть Голлла/ндиї, о радостию жителе, / с Колна ж в' Базилию. Тамъ оставивъ карабли / ї ину утварь, їде пьша в’ Римъ иже обшедъ мъста всъ в’ Риме по обещанию / во ${ }^{3}$ вратиска в Басилию. Папа ж Кириа ${ }^{\kappa}$ веде ю / с велиею честию даже до мъста.

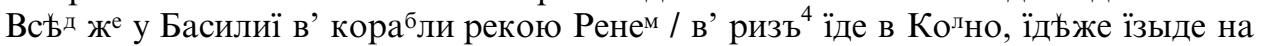
брег / не въдағ о неприғателе, но чағ нкко и преж/де безопасно быти. Внегда ж град૪ прибли/жашеск, абие ю о ${ }^{\mathrm{T}}$ всюд૪ венгры обско/чиша и 3 дъввами всбми смерти преда/ша. Сице бл̃городнаға дв̈ца со Етерием / женихомъ своимъ иже свъдавъ Урсулю / во ввращающ४сғ с мт̃рию ї сестрою Өло/рентиною, ї с нъкими епскопы даже / до Колна в' срьтение еА изыде ї с Кириаком / папою, ї со в'сьми дв̈цы мира сего избы ть (л. 77 об.:) принесе. Тъхъ девицъ телеса лежа ${ }^{\mathrm{T}} /$ в Ко погребъ / положены суть. Сею повъстию тогш / длғ ръчь перерваль, нко ї в литовских / старыхъ 5 льтопискахъ о разорениї / Атили ї ४биениї ғаї. дъвъ ї о вине / прихода ${ }^{6}$ Палемонова с ыталиань в Ли/тву бутто чре ${ }^{3}$ сонъ воспоминаюю ради в междометиї положихъ].

$\mathrm{A}^{\mathrm{T}}$ тилға ж в Венгры возвративск, Бдду / брата ъби ғако Сикамврию от своего име/ни нарече, однако жъ его Будою / зовутъ имже о венгры, търокъ вла/дъетъ $[\ldots]$

(ГИМ, Музейное собрание, № 1391, л. 76-77об)

4 Буква з написана по какой-то другой букве, скорее всего, по $м$, т. е. здесь было написано первоначально в' римъ ('в Рим'), что было исправлено только частично. По смыслу должно быть в'низъ 'вниз', ср. у Стрыйковского (1582, 57): «Renem rzeką ná dot iácháłá do Kolná» и в русском переводе 1688 г. (ГИМ, Ув. собр. № 4, л.. 113об): «Реном рекою / на низ шествова до Околна».

${ }^{5}$ Исправлено из страрыхъ.

${ }^{6} a$ исправлено из $\varnothing$. 
6.

Русский перевод 1688 г.

(л. 112:) [...] Гихл૪ воєводъ // (л. 112 об.:) под Колно посла, киї обозы / своА на

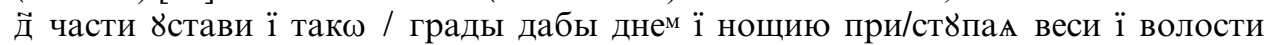
кругомъ / множественно разорна; /

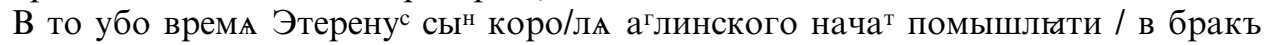
брытенского королА о едино/родно ишери, Послаше с велиею / охотою послы

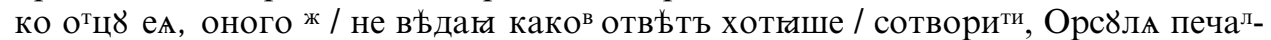

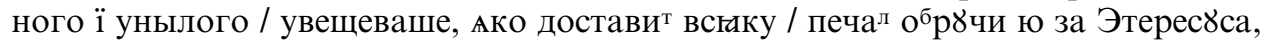
повъдаА / что имать сие нвление о ог̃

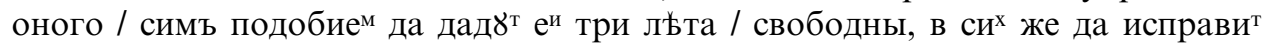

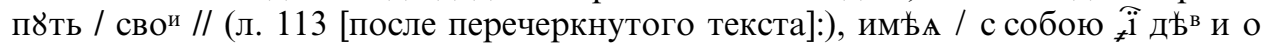

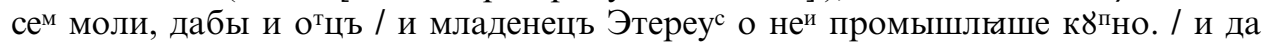

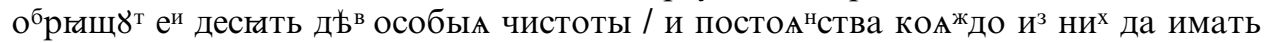

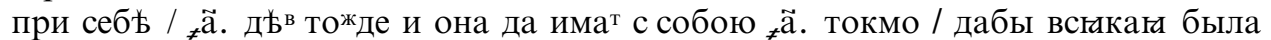

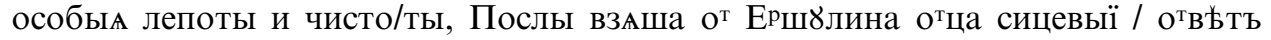
с радостию отойдоста; //

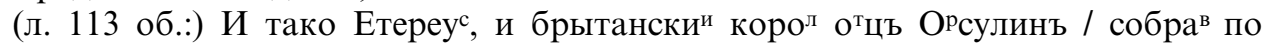

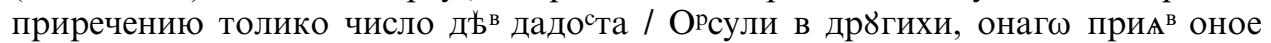

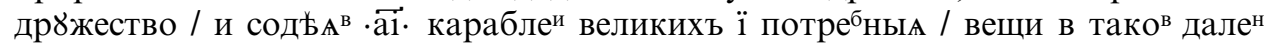
п४ть, иде морем ${ }^{3}$ Брыта/ниї даже до оногш мъста идъже река Ренъ / в море впадае ${ }^{\mathrm{T}}$, гдъ нн̈е есть часть Голандиї / от тбд૪ ж паки против воды рекою приплы / до Колна Аграпины, и с великою радостию / гражда лию остави ${ }^{\text {в }}$ тамо ${ }^{7}$ всн / мъста в Римъ, нко обещасн возвратиса / в Базилию.

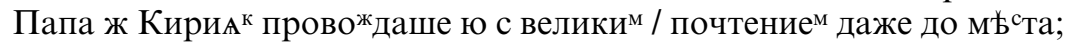

Вседоста же у Базилиї в караб ли Рено ${ }^{\mathrm{m}}$ рекою / на ни ${ }^{3}$ шествова до Околна, и

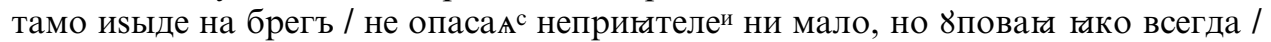
в тишинь тако бұде обыдоша / венгры, и со всъми оными дъвами зль побиша, // (л. 114:) онаА ж

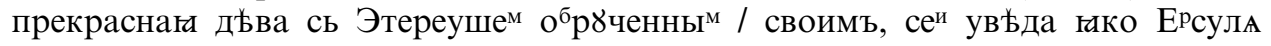
наsадь / во вращаетсА, с материю и сестрою Өло/рен тиною и с нбкоими про чими епископы / аже до Колна во стрьтение еА пришествова, / и со оны ${ }^{\mathrm{M}}$ папою Киринко м и со всъми оными / дъвами отыде с сего свъта, чистоту же / свою

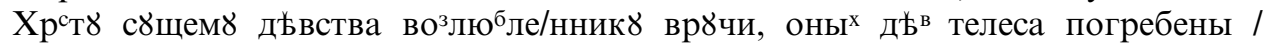
в Колне, по сем же кости и ${ }^{\mathrm{x}}$ положены / суть в великиї погре ${ }^{б}$, Сию историю / того ради прекратихъ, зане в литовски / льтописцахъ ї о погромлени Атила и о

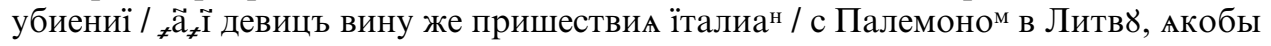
во снъ несовер/шенно воспоминае ${ }^{\mathrm{T}}$, и сего ради во вместителны ${ }^{\mathrm{x}}$ положихъ, Возвративше же са в Вен грию, замучи брата, // (114 об.:) Зане Сикамбрию о

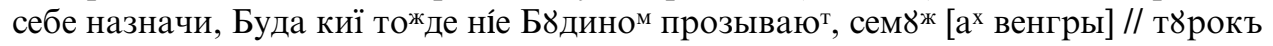
нн̈е главою [...].

(ГИМ, Уваровское собрание, № 4, л. 112-114об)

7 Далее переводчиком или писцом пропущена одна строка, ср. у Стрыйковского «Tám zoftáwiwfzy okręty y infse fprzęty, f̧łá pief̧so do Rzyma, ktora / potym obchodziwfsy mieyfcá wfзytki w Rzymie» (Stryjkowski 1582, 52) или в русском переводе 1673-1679 гг.: «Тамъ оставивъ карабли / ̈̈ ину утварь, їде птьша в’ Римъ иже общедъ мъста всъ в’ Риме» (ГИМ, Музейное собрание, № 1391, л. 77).

Studia Slavica Hung. 48, 2003 


\section{Литература}

Атыля 1580 - Исторығ $\omega$ Ятүыми коро “и 8горұскомъ. - Biblioteka Raczyńskich w Poznaniu, Rękopis nr 94, s. 173-224.

Веселовскій 1888 - А. Н. ВЕСЕЛОвскІй, Изъ исторіи романа и повђсти. СанктъПетербургъ 1888. (= Сборникъ Отдъленія русскаго языка и словесности, т. 44, № 3)

Золтан 1999 - А. ЗолтАН, Венгерский вклад в книжную культуру Великого княжества Литовского эпохи Ренессанса (Athila М. Олаха в польском и старобелорусском переводе). - In: Мартинас Мажвидас и духовная культура Великого княжества Литовского XVI века. Ред. колЛегия: Ю. БУдРАЙтИС, С. ЖУКАС, Д. КУОЛИС, Ю. ЛАБЫнЦЕВ, В. ТОПОРОВ, Л. ЩАВИНСКАЯ. ВИЛЬнюс-Москва 1999, 72-92.

Микитась 1988 - Українська література XIV-XVI ст. Автор вступної статті і редактор тому В. Л. МикитАсь (= Бібліотека української літератури). Київ 1988.

Рогов 1966 - А. И. Рогов, Русско-польские культурные связи в эпоху Возрождения (Стрыйковский и его Хроника). Москва, 1966.

Соболевскій 1903 - А. И. СоБОлЕвскій, Переводная литература Московской Руси XIV-XVII в ьковъ, Библіографическіе матеріалы. С.-Петербургъ, 1903.

Bardach 1967 - Juliusz BARDACH, Kronika Macieja Stryjkowskiego i jej rozpowszechnienie w Rosji [w związku z książką A. I. Rogowa ...]: Przegląd Historyczny 58 (1967), 326-336.

Bazylik 1574 - [Титульный лист:] Hiftoria / fpraw Atyle / Krolá Węgier-/Ikiego. Z Łacińlkiego ięzyká ná / Polfki przełożoná / przez Cyprianá / Bazyliká. Cum gratia et priuilegio. [Ha последней странице:] W Krákowie. / Drukował Máciey Wirzbiętá, / Typograph $\mathrm{Je}^{0} \mathrm{~K}$. M. Ro-/ku Páńlkiego, // 1574.

Bäuml and Birnbaum 1993 - Attila. The Man and His Image. Edited by FranZ H. BÄUML and MARIANNA D. BiRnBAum. Budapest 1993.

Bonfini 1936 - ANTONIUS DE Bonfinis, Rerum Ungaricarum Decades. Ediderunt I. Fógel et B. IVÁNYI et L. JuhÁsz. In IV tomis. Tomus I. Lipsiae 1936 (= Bibliotheca Scriptorum Medii Recentisque Aevorum. Redigit LadisLaus JuHÁsz, Saeculum XV).

Brückner 1886 - A. BRÜCKNER, Ein weissrussischer Codex miscellaneus der Gräflich-Raczyński’schen Bibliothek in Posen. In: Archiv für slavische Philologie 9 (1886) 345-391.

CathEn - The Catholic Encyclopedia [1913]. Online Edition by KeVIn KnIGHT, 2002 (http://www.newadvent.org/cathen/)

Eckhardt 1940 - ECKHARDT SÁNDOR, Attila a mondában. In: Németh 1940, 143-216.

Estreicher XIV — KAROL EstreICHER, Bibliografia polska XIV, Kraków 1896.

Graciotti 1973 - SANTE GRACIOTTI, L'«Athila» di Miklós Oláh fra la tradizione italiana e le filiazioni slave. In: Venezia e Ungheria nel Rinascimento. A cura di VitTore BrancA. Firenze 1973, $275-316$.

KatLex — Katolikus lexikon. Szerk. BANGHA BÉLA. I-IV. Budapest, 1931-1933.

Krzyżanowski 1926 - Julian KRZYŻAnOwSKI, Romans pseudohistoryczny w Polsce wieku XVI. Kraków 1926 (= Prace Historyczno-Literackie 25).

Löfstedt 1993 - LEENA LÖFSTEDT, Attila, the Saintmaker in Medieval French Vernacular. In: Bäuml and Birnbaum 1993, 65-74.

Németh 1940 - Attila és hunjai. Szerkesztette NÉMETH GYULA. Budapest 1940.

Olahus 1938 - Nicolaus Olahus, Hungaria - Athila. Ediderunt Colomannus EperJessy et Ladislaus JuHÁsz. Budapest 1938 (= Bibliotheca Scriptorum Medii Recentisque Aevorum IOSEPHO FóGEL Moderante. Redigit LADISLAus JuHÁsZ, Saeculum XVI).

ÖHL — JOACHIM SCHÄFER, Ökumenisches Heiligenlexikon. Stuttgart 2002. (http://www.heiligenlexikon.de/index.htm)

Piekarski I - KaZIMIERZ PieKARSKI, Katalog Bibljoteki Kórnickiej. Tom I: Polonica XVI-go wieku. Kraków 1929.

Polonia Typographica XI - Polonica Typographica saeculi sedecimi - Tłocznie polskie XVI stulecia. Monografie i podobizny zasobów drukarskich. Fasc. XI: Maciej i Paweł Wirzbiętowie, Kraków 1555/7-1609. Opracowała Alodia KaweCKA-Gryczowa. Wrocław-Warszawa-Kraków-Gdańsk 1981. 
Stryjkowski 1582 - Ktora przed-/tym nigdy fwiá-/tłá niewidziáłá. / Kronika Pol-/lka Litewfka, Zmodźka, y wßyft-/kiey Rufi Kijowfkiey, Molkiewfkiey, Siewierlkiey, Woł-/yńlkiey, Podolfkiey, Podgorlkiey, Podlálkiey, etc. Y rozmáite przypadki / woienne y domowe, Prufkich, Mázowieckich, Pomorfkich, y inßych kráin / Kroleftwu Polfkiemu y Wielkiemu Xięftwu Litewfkiemu przyległych, / Według iftotnego y gruntownego zniefienia pewnych dowodow z rozmái-/tych Hiftorikow y Autorow poftronnych, y domowych, y Kijowfkich, Mo-/fkiewfkich, Sławáńfkich, Liflantfkich, Prufkich ftárych, Dotąd ciemnochmur-/ną nocą zákrytych Kronik, y Látopisczow Rulkich, Litewfkich, y DŁUGO-/SZA Oycá dzieiow Polfkich z inßymi, z wielką pilnofcią y węzłowatą / pracą (Ofobliwie około Dzieiow Litewlkich y Rufkich od / żadnego przedtym niekußonych) Przez MACIEIA OSOSTEWICIVSA STRIY-kowfkiego dostátecznie nápifána, złożona, y ná fwiátło z wybádo-/nim prawdziwie dowodney ftárodawnofći włafnym wynálezienim, / przeważnym dochćipem, y nakłádem nowo wydźwigniona / przez wßyftki ftárożytne wieki, áż do dzifiey-/ßego Roku 1582. A naprzod wßyftkich ile ich kolwiek ieft ludzkich ná / Swiecie Narodow gruntowne wywody. / Z fáfką y Priwileiem Kro: J: M: / Drukowano w Krolewcu v Gerzego Ofterbergerá: / M. D. LXXXII.

Stryjkowski 1846 - Kronika polska, litewska, żmódzka i wszystkiéj Rusi Macieja Stryjkowskiego. Wydanie nowe, będące powtórzeniem wydania pierwotnego królewieckiego z roku 1582, poprzedzone wiadomością o życiu i pismach Stryjkowskiego przez Mikołaja Malinowskiego, oraz rozprawą o latopiscach ruskich przez Daniłowicza, pomnożone przedrukiem dzieł pomniejszych Stryjkowskiego według pierwotnych wydań. Tom I. Warszawa 1846.

Stryjkowski 1978 - MACIEJ STRYJKOWSKI, O początkach, wywodach, dzielnościach, sprawach rycerskich i domowych sławnego narodu litewskiego, żemojdzkiego i ruskiego, przed tym nigdy od żadnego ani kuszone, ani opisane, z natchnienia Bożego a uprzejmie pilnego doświadczenia. Opracowała Julia RADZISZEWSKA. Warszawa 1978.

Wierzbowski I-III - Teodor WIERZBOWSKI, Bibliographia Polonica XV ac XVI saeculorum. T. IIII. Kraków 1889-1994.

Zoltán 1996 - A. ZoLTÁN, Z węgiersko-polsko-białoruskich związków kulturalnych („Athila” M. Oláha w przekładzie polskim i białoruskim). In: Acta Polono-Ruthenica I (Olsztyn 1996), $427-435$.

Zoltán 2000 - A. Zoltán, К изучению старобелорусской Исторыи о Атыли (О существующих изданиях текста). In: Studia Russica 18 (Budapest 2000) 328-332.

Zoltán 2000a - ZolTÁN ANDRÁs, Maciej Stryjkowski esete a Szent Orsolya-legendával. In: Polono-Hungarica 8, Nyelvészet-Irodalom-Történelem-Kultúrtörténet. Az 1998. november 9-én és 10-én tartott nemzetközi tudományos konferencia anyaga. Szerk. BAŃCZEROWSKI JANUSZ. Budapest 2000, 169-179.

Zoltán 2001 - A. ZoLTÁN, Rekonstrukcja zaginionych fragmentów Bazylikowego przekładu Athili M. Oláha (1574). In: Studia Slavica Hung. 46 (2001) 13-23.

Zoltán 2001a - A Stryjkowski-krónika egy magyar forrása. In: Lengyelek és magyarok Európában, Nyelv, irodalom, kultúra - párhuzamok és kapcsolatok. Tanulmányok D. Molnár István profeszor tiszteletére. Válogatta és szerkesztette NAGY LÁszLó KÁLMÁN. Debrecen 2001, 102106.

Zoltán 2001b - ZoLTÁN ANDRÁs, Callimachus vagy Olahus? (Egy régi tévedés nyomában). In: Hungaro-Slavica 2001. Studia in honorem Iani Bańczerowski. Adiuvantibus S. RÁduly, A. Zoltán et I. KÁlmán editionem curante P. PÁtrovics redigit IstVÁn NyOMÁrkaY. Budapest 2001, 318-321. 